\title{
Novel azithromycin derivatives with the C-4" bisamide side chains: synthesis and biological evaluation against gram-positive bacteria
}

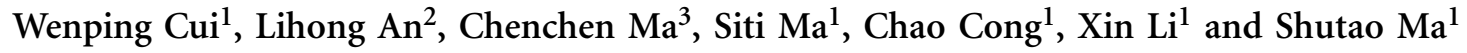 \\ Novel azithromycin (AZM) derivatives with the C-4" bisamide side chains were synthesized and evaluated for their in vitro \\ antibacterial activities. The $4^{\prime \prime}-O$-(benzamido)alkyl carbamates showed excellent activity against the erythromycin-susceptible \\ Streptococcus pneumoniae and exhibited greatly improved activity against erythromycin-resistant $S$. pneumoniae. Among them, \\ compounds $5 \mathrm{~g}$ and $6 \mathrm{~g}$, which had the same electron-withdrawing group, 3,5-dinitrophenyl, on the termination of their C-4" \\ bisamide side chains, demonstrated the most potent activity against erythromycin-resistant $S$. pneumoniae expressing the erm \\ gene, the mef gene and the erm and mef genes, showing 128-fold, 33-fold and 32-fold improved activity in comparison with the \\ parent AZM.
}

The Journal of Antibiotics advance online publication, 15 February 2012; doi:10.1038/ja.2012.3

Keywords: antibacterial activity; azithromycin derivatives; resistant bacteria; synthesis

\section{INTRODUCTION}

Macrolide antibiotics have been commonly used effectively and safely for the treatment of respiratory tract infections since the first macrolide erythromycin A was used clinically in the early 1950's. However, intensive emergence of the resistance to various antimicrobials is a pandemic phenomenon, which severely threatens therapeutic effectiveness of the macrolides as well. ${ }^{1}$ To overcome the resistance of bacteria to the macrolides, the structural modifications of existing macrolide antibiotics such as clarithromycin ${ }^{2}$ and azithromycin ${ }^{3}$ (AZM) have been carried out, leading to the discovery of thirdgeneration macrolides known as ketolides. Telithromycin, a typical example of ketolides, which is well known for excellent activity against resistant strains and lower inductivity of the erm gene encoding resistance, has been launched in the market. ${ }^{4-6}$ It has been reported that the C-11,12 prolonged carbamate side chain of telithromycin can interact with a secondary ribosomal binding site A752 directly in domain II of the 23S rRNA in addition to the main interaction with A2058 in domain $\mathrm{V}$, resulting in tighter binding to bacterial ribosomes and improved activity against erm-resistant organisms. ${ }^{7}$ Another promising ketolide, cethromycin, ${ }^{8}$ which can also interact with A752 through its C-6 prolonged side chain, is in last-stage development at present. Unfortunately, severe hepatotoxicity suppressing the clinical use of telithromycin has been reported. Great efforts to develop new generation macrolides with low toxicity and potent activity have led to the discovery of the C- $4^{\prime \prime}$ modified macrolides such as CP- $544372^{9}$ and A-66332. ${ }^{10}$ CP-544372, which contains a long C- 4 " anchor group with six atoms from the $4^{\prime \prime}$-oxygen atom to the terminal aromatic ring, exhibits excellent in vitro and in vivo activity against macrolideresistant strains encoded by the erm gene. ${ }^{11}$ It has been revealed that the side chains of CP-544372 can reach the chloramphenicol-binding sites in the peptidyl transferase center region ${ }^{9}$ and impart a higher affinity to the resistant ribosomes.

To explore the contribution of length of the $\mathrm{C}-4$ " side chains to the antibacterial activity, several series of novel $4^{\prime \prime}$-O-carbamate derivatives of AZM, characterized by novel C- $4^{\prime \prime}$ arylalkyl groups with three, four, eight and nine atoms from the $4^{\prime \prime}$-oxygen atom to the terminal aromatic ring, were designed, synthesized and evaluated in our research group. The $4^{\prime \prime}$-O-carbamates containing short side chains with three or four atoms from the $4^{\prime \prime}$-oxygen atom to the terminal aromatic ring not only retained the activity against susceptible Streptococcus pneumoniae, but also showed improved activity against resistant $S$. pneumoniae encoded by the erm gene, and the erm and mef genes in comparison with macrolide erythromycin A, clarithromycin and AZM. ${ }^{12}$ Especially, the $4^{\prime \prime}$-O-carbamates with long side chains, the lengths of which are eight or nine atoms from the $4^{\prime \prime}$-oxygen atom to the terminal aromatic ring, showed more remarkably improved activity against the resistant strains encoded by the erm gene, and the erm and the mef genes than the above references and the $4^{\prime \prime}$-O-carbamates with short side chains, which suggested that the $4^{\prime \prime}$-O-carbamates with long side chains could have good activity against the resistant strains. ${ }^{13}$ On the basis of the above results, two series of novel AZM derivatives with the C-4" bisamide side chains

${ }^{1}$ Department of Medicinal Chemistry, School of Pharmaceutical Sciences, Shandong University, Jinan, PR China; ${ }^{2}$ Department of Occupational and Environmental Health Sciences, School of Public Health, Shandong University, Jinan, PR China and ${ }^{3}$ Reyoung Pharmaceutical Co., Ltd, Yi Yuan, PR China 
containing six or eight atoms from the $4^{\prime \prime}$-oxygen atom to the terminal aromatic ring were designed, synthesized and evaluated for their in vitro antibacterial activities in this paper. The introduced C- $4^{\prime \prime}$ bisamide side chains were expected to interact with the new binding sites in the peptidyl transferase center region ${ }^{14}$ and produce an additional affinity for the resistant ribosome through hydrogen bonding, $\pi$-stacking and electrostatic interactions. ${ }^{13}$

\section{RESULTS}

\section{Chemistry}

The synthesis of $4^{\prime \prime}$-O-(benzamido)alkyl carbamates of 11,12-cyclic carbonate AZM 5a-g and $\mathbf{6 a - g}$ started from the commercially available AZM (Scheme 1). 2'-O-acetylation of AZM with acetic anhydride $\left(\mathrm{Ac}_{2} \mathrm{O}\right)$ was followed by introduction of $\mathrm{C}-4^{\prime \prime}$ acylimidazole group and 11,12 -cyclic carbonate group utilizing $1,1^{\prime}$-carbonyldiimidazole in the presence of triethylamine to generate $4^{\prime \prime}$-O-acylimidazolide (2). The reaction of 2 with ethylenediamine or 1,4-butanediamine hydrochloride catalyzed by 1,8 -diazabicyclo(5.4.0) undec-7-ene provided $4^{\prime \prime}-O$ (2-aminoethyl)carbamate (3) or $4^{\prime \prime}-O$-(4-aminobutyl)carbamate (4), respectively. Finally, $4^{\prime \prime}-O$-(benzamido)ethyl carbamates of 11,12-cyclic carbonate AZM (5a-g) and $4^{\prime \prime}-O$-(benzamido)butyl carbamates of 11,12-cyclic carbonate AZM $(\mathbf{6 a}-\mathbf{g})$ were obtained by the condensation of $\mathbf{3}$ or $\mathbf{4}$ with the corresponding substituted benzoic acid in the presence of 1,3-dicyclohexylcarbodiimide and 1-hydroxybenzotriazole, and the subsequent $2^{\prime}$-O-deacetylation at $55^{\circ} \mathrm{C}$ in methanol in yields ranging from 75.8 to $87.6 \%$.

\section{Antibacterial activity}

The in vitro activities of the $4^{\prime \prime}-O$-(benzamido)alkyl carbamates $\mathbf{5 a}-\mathbf{g}$ and $\mathbf{6 a -} \mathbf{g}$, as well as macrolide erythromycin A, clarithromycin and AZM as references, were evaluated by using broth microdilution method as shown in Table 1. S. pneumoniae ATCC49619 is an erythromycin-susceptible strain, and S. pneumoniae B1, S. pneumoniae A22072 and S. pneumoniae AB11 are three erythromycin-resistant strains whose resistance were encoded by the erm gene, the mef gene, and the erm and mef genes, respectively. Staphylococcus aureus
ATCC25923 is an erythromycin-susceptible strain. S. aureus and S. aureus ATCC29213 are penicillin-resistant and methicillin-resistant strains, respectively.

MIC values for $4^{\prime \prime}$-O-(benzamido)alkyl carbamates of 11,12-cyclic carbonate AZM 5a-g and $\mathbf{6 a -} \mathbf{- g}$ are presented in Table 1 . Most of the $4^{\prime \prime}$-O-(benzamido)alkyl carbamates showed excellent activity (0.5$0.12 \mu \mathrm{g} \mathrm{ml}^{-1}$ ) against the erythromycin-susceptible $S$. pneumoniae ATCC49619. Among them, compounds 5g, 6f and 6g, which had the electron-withdrawing groups on the termination of their C- $4^{\prime \prime}$ bisamide side chains, were found to have the most potent activity $\left(0.12 \mu \mathrm{g} \mathrm{ml}^{-1}\right)$, but weaker than the parent AZM. In particular, the most active compounds $\mathbf{5 g}$ and $\mathbf{6} \mathbf{g}$ possessed the same terminal group, 3,5-dinitrophenyl, on their C- $4^{\prime \prime}$ bisamide side chains, but the side chain of the former was two atoms less than that of the latter. As for the activity against three erythromycin-resistant $S$. pneumoniae strains, all of the $4^{\prime \prime}-O$-(benzamido)ethyl carbamates $\mathbf{5 a}-\mathbf{g}$ exhibited improved activity against erythromycin-resistant $S$. pneumoniae expressing the erm gene, and the erm and mef genes, showing 4-128-fold and 4-32fold better activity than the parent AZM, respectively. Among them, compounds $\mathbf{5 f}$ and $\mathbf{5 g}$ showed potent activity $\left(0.5-0.12 \mu \mathrm{g} \mathrm{ml}^{-1}\right)$ against erythromycin-resistant $S$. pneumoniae A22072 expressing the mef gene. Especially, compound $\mathbf{5 g}$ presented the most potent activity ( 1 and $0.12 \mu \mathrm{g} \mathrm{ml}^{-1}$ ) against erythromycin-resistant $S$. pneumoniae strains expressing the erm gene or the mef gene, exhibiting 128-fold and 33-fold better activity than the parent AZM. On the other hand, all of the $4^{\prime \prime}-O$-(benzamido)butyl carbamates 6a-g had improved activity against erythromycin-resistant $S$. pneumoniae expressing the erm gene, the mef gene, and the erm and mef genes, exhibiting 4-128fold, 4-32-fold and 8-32-fold higher activity than the parent AZM, respectively. Among them, compounds $\mathbf{6 a}, \mathbf{6 b}, \mathbf{6 f}$ and $\mathbf{6 g}$ displayed significantly potent activity $\left(0.5-0.12 \mu \mathrm{g} \mathrm{ml}^{-1}\right)$ against erythromycinresistant S. pneumoniae A22072 expressing the mef gene, and compound $\mathbf{6 g}$ showed potent activity $\left(1 \mu \mathrm{g} \mathrm{ml}^{-1}\right)$ against $S$. pneumoniae $\mathrm{B} 1$ expressing the erm gene. In particular, compound $6 \mathrm{~g}$ possessed the highest activity against erythromycin-resistant $S$. pneumoniae expressing both the erm gene and the mef gene, comparable to compound $5 \mathrm{~g}$.

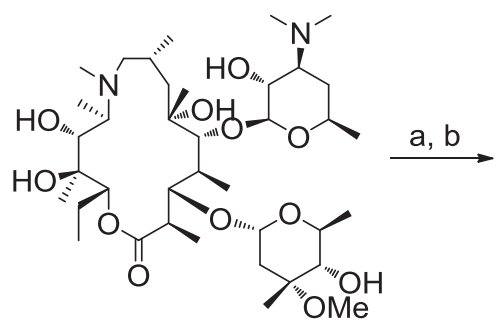

AZM

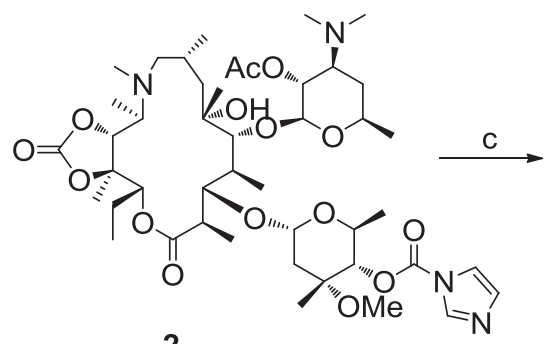

2

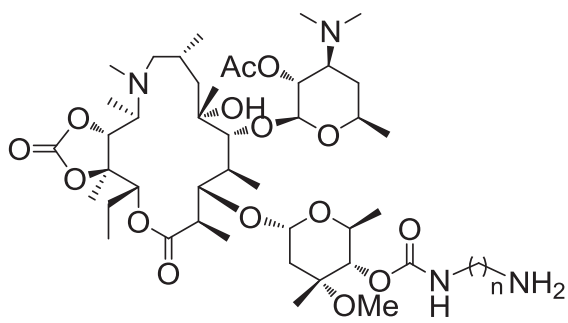

$3(n=2)$ or $4(n=4)$

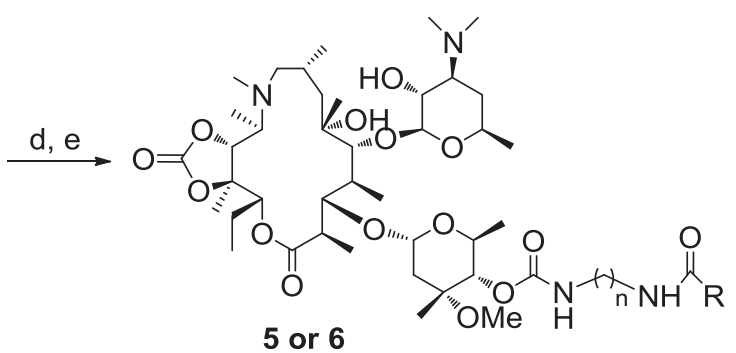
5a $n=2$ R=4-methoxyphenyl
6a $n=4 \quad R=4-m e t h o x y p h e n y l$
5b $n=2$ R=2-methoxyphenyl
6b $n=4 \quad R=2-$ methoxyphenyl
5c $n=2$ R=3,4-dimethoxyphenyl 6c $n=4 \quad R=3,4$-dimethoxyphenyl
5d $\mathrm{n}=2 \mathrm{R}=4$-chlorophenyl
6d $n=4 \quad R=4$-chlorophenyl
5e $n=2 \quad R=2,4$-dichlorophenyl
6e $n=4 \quad R=2,4$-dichlorophenyl
$6 f \mathrm{n}=4 \mathrm{R}=4$-nitrophenyl
$5 f \quad n=2 \quad R=4-n i t r o p h e n y l$
5 g $n=2 \quad R=3,5$-dinitrophenyl

Scheme 1 Reagents and conditions: (a) $\mathrm{Ac}_{2} \mathrm{O}, \mathrm{CH}_{2} \mathrm{Cl}_{2}, \mathrm{Et}_{3} \mathrm{~N}$, room temperature, $12 \mathrm{~h}, 96 \%$; (b) $1,1^{\prime}$-carbonyldiimidazole, toluene, $55{ }^{\circ} \mathrm{C}, 48 \mathrm{~h}, 87 \%$; (c) Ethylenediamine or 1,4-butanediamine hydrochloride, 1,8-diazabicyclo(5.4.0)undec-7-ene, Et $3 \mathrm{~N}$, room temperature, 4h, 93\%; (d) R-COOH, 1,3dicyclohexylcarbodiimide, 1-hydroxybenzotriazole, tetrahydrofuran, $0{ }^{\circ} \mathrm{C}, 0.5-1 \mathrm{~h}$; room temperature, $2 \mathrm{~h}, 86-90 \%$; $(\mathrm{e}) \mathrm{CH}{ }_{3} \mathrm{OH}, 55{ }^{\circ} \mathrm{C}, 24 \mathrm{~h}, 76-88 \%$. 
Table 1 In vitro antibacterial activity of $4^{\prime \prime}-0$-(benzamido)alkyl carbamates of 11,12-cyclic carbonate azithromycin

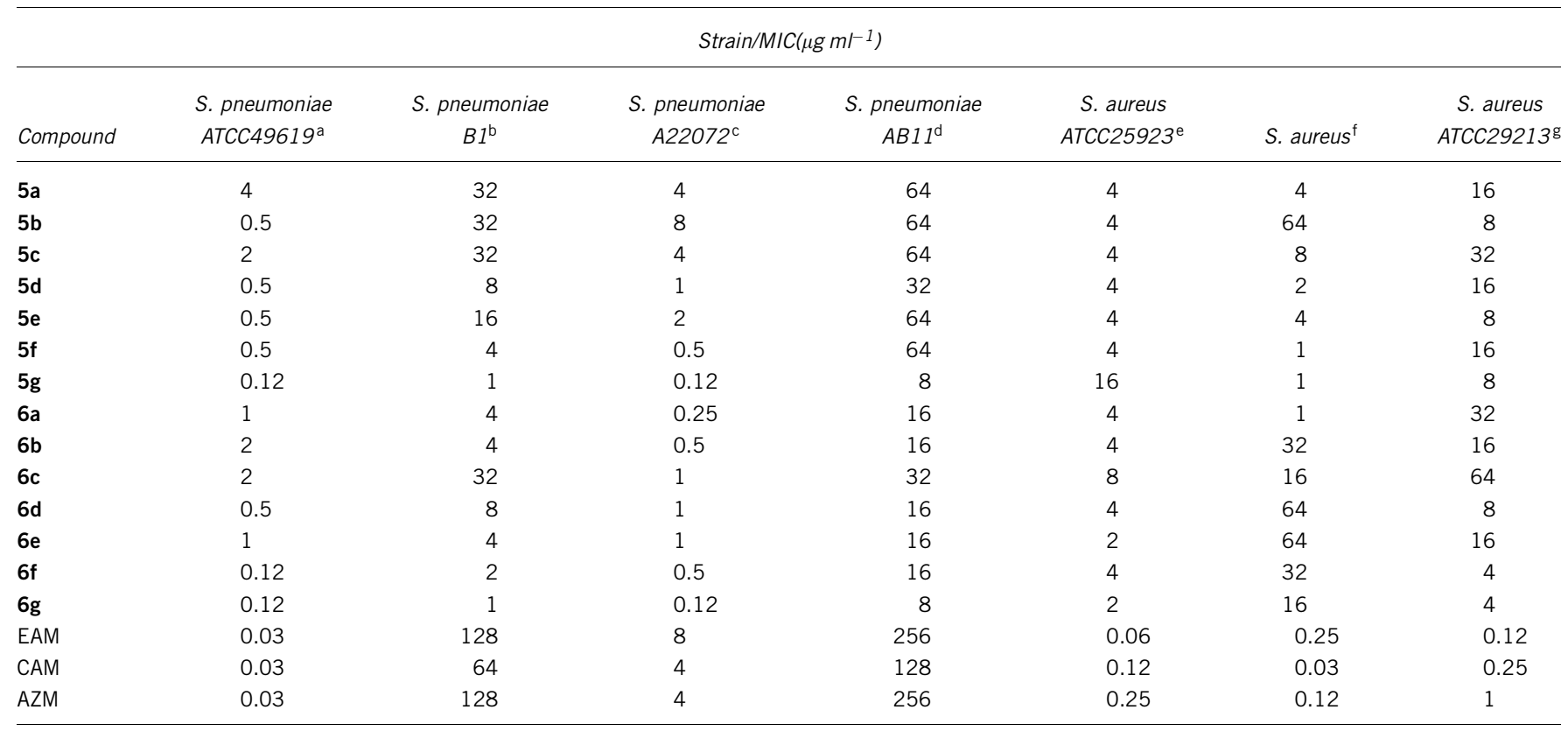

Abbreviations: AZM, azithromycin; CAM, clarithromycin; EAM, macrolide erythromycin A.

as. pneumoniae ATCC49619: erythromycin-susceptible strain.

bS. pneumoniae B1: erythromycin-resistant strain encoded by the erm gene

CS. pneumoniae A22072: erythromycin-resistant strain encoded by the mef gene.

dS. pneumoniae AB11: erythromycin-resistant strain encoded by the erm and mef genes.

eS. aureus ATCC25923: erythromycin-susceptible strain.

${ }^{\mathrm{f}} \mathrm{S}$. aureus: penicillin-resistant strain isolated clinically, not characterized.

g. aureus ATCC29213: methicillin-resistant strain.

Although the most active compounds $5 \mathbf{g}$ and $\mathbf{6 g}$ possessed different length of the C-4" bisamide side chain, they had the same electronwithdrawing group, 3,5-dinitrophenyl, on the termination of $\mathrm{C}-4^{\prime \prime}$ bisamide side chain.

\section{DISCUSSION}

On the whole, the series of $4^{\prime \prime}$-O-(benzamido)butyl carbamates with eight atoms from the $4^{\prime \prime}$-oxygen atom to the terminal benzene ring on the C- 4 " bisamide side chains showed more greatly improved activity against the erythromycin-resistant $S$. pneumoniae than the series of $4^{\prime \prime}$ $O$-(benzamido)ethyl carbamates with six atoms from the $4^{\prime \prime}$-oxygen atom to the terminal benzene ring. In addition, the compounds with the electron-withdrawing groups showed higher activity against the tested erythromycin-resistant $S$. pneumoniae than those with the electron donating groups in the series of $4^{\prime \prime}-O$-(benzamido)ethyl carbamates. The results described above indicated that the C- $4^{\prime \prime}$ elongated bisamide side chain with eight atoms between the $4^{\prime \prime}$-oxygen atom and the terminal aromatic ring might be a suitable length, and the terminal 3,5-dinitrophenyl group might easily interact with the new binding sites of nucleotides in the peptidyl transferase center region through hydrogen bonding, $\pi$-stacking etc., resulting in a higher affinity for the ribosome of resistant bacteria.

In contrast to the greatly improved activity against the erythromycin-resistant $S$. pneumoniae strains, the $4^{\prime \prime}$-O-(benzamido)alkyl carbamates $\mathbf{5 a}-\mathbf{g}$ and $\mathbf{6 a}-\mathbf{g}$ lost activity against the erythromycin-susceptible and resistant $S$. aureus strains compared with the parent AZM. This result led us to presume that the long $\mathrm{C}-4^{\prime \prime}$ bisamide side chains on the $4^{\prime \prime}$-O-(benzamido)alkyl carbamates could not interact with the secondary ribosomal binding sites in the peptidyl transferase center region, and further block the interaction of the $4^{\prime \prime}$-O-(benzamido)alkyl carbamates with the main binding site A2058 in ribosomes of S. aureus as well.

In summary, novel $4^{\prime \prime}-O$-((benzamido)alkyl carbamates of 11,12 cyclic carbonate AZM were designed, synthesized and evaluated for their in vitro antibacterial activities. Most of the $4^{\prime \prime}-O$-(benzamido)alkyl carbamates showed excellent activity against the erythromycin-susceptible S. pneumoniae and some of them exhibited greatly improved activity against erythromycin-resistant $S$. pneumoniae expressing the erm gene, the mef gene, and the erm and mef genes. Among them, compounds $\mathbf{5 g}$ and $\mathbf{6 g}$, which had the same electronwithdrawing group, 3,5-dinitrophenyl, on the termination of their C- 4 " bisamide side chains, demonstrated the most potent activity against the erythromycin-susceptible and erythromycin-resistant $S$. pneumoniae. It is noteworthy that the series of $4^{\prime \prime}$-O-(benzamido)butyl carbamates with eight atoms from the $4^{\prime \prime}$-oxygen atom to the terminal benzene ring on the C- 4 " bisamide side chains showed more greatly improved activity against the erythromycin-resistant $S$. pneumoniae than the series of $4^{\prime \prime}-O$-(benzamido)ethyl carbamates with six atoms from the $4^{\prime \prime}$-oxygen atom to the terminal benzene ring.

\section{METHODS}

\section{General experimental procedures}

All necessary solvents were purified before use, unless noted otherwise. Reactions were monitored by thin-layer chromatography (TLC), using 0.25$\mathrm{mm}$ pre-coated silica gel plates (Qingdong Yumingyuan silica gel reagent factory, Shandong, China, YUYUAN). TLC was detected by UV detector at $254 \mathrm{~nm}$ and sulfuric acid color reaction. Flash chromatography was performed with the indicated solvents using silica gel 60 (particle size $0.040-0.063 \mathrm{~mm}$, Qingdong Yumingyuan silica gel reagent factory). IR spectra were recorded on KBr pellets using Nicolet Nexus 470FT-IR spectrometer (Nicolet, Madison, WI, 
USA). ${ }^{1} \mathrm{H}$ NMR spectra were recorded on a Bruker Avance DRX 600 spectrometer (Bruker, Fällanden, Switzerland) at ambient temperature with tetramethylsilane as an internal standard. Mass spectra were recorded on an API 4000 instrument (Applied Biosystems, Foster City, CA, USA) and the highresolution mass spectra data were obtained using Agilent Q-TOF6510 mass spectrometer (Agilent Technologies, Santa Clara, CA, USA). UV spectra were obtained on Shimadzu UV-2550 spectrometer (Shimadzu, Tokyo, Japan). The m.p. are uncorrected and were determined on an X-6 melting point apparatus (Beijing Tianchengwode Biotech Co. Ltd, Beijing, China). AZM that was used as starting material was obtained from Nexchem Pharmaceutical Co., Ltd (Jinhuacity, Zhejiang, China).

\section{$2^{\prime}$-O-acetyl-4" $-O$-acylimidazolyl AZM-11,12-carbonate (2)}

To a solution of AZM $(2.0 \mathrm{~g}, 2.67 \mathrm{mmol})$ in dichloromethane $(20 \mathrm{ml})$ at room temperature was added $\mathrm{Ac}_{2} \mathrm{O}(0.7 \mathrm{ml}, 7.38 \mathrm{mmol})$ and $\mathrm{Et}_{3} \mathrm{~N}(3.00 \mathrm{ml}$, $21.65 \mathrm{mmol}$ ). The resulting solution was allowed to stir for $12 \mathrm{~h}$ at room temperature. The reaction was quenched with $5 \%$ aqueous $\mathrm{NaHCO}_{3}(20 \mathrm{ml})$ and the aqueous layer was extracted with dichloromethane $(3 \times 10 \mathrm{ml})$. The combined organic layers were dried over anhydrous $\mathrm{Na}_{2} \mathrm{SO}_{4}$, filtered and concentrated in vacuo to afford $2.02 \mathrm{~g}(95.6 \%)$ of acetate product as a white solid: m.p. $167-170{ }^{\circ} \mathrm{C}, \mathrm{R}_{\mathrm{f}}=0.52$ (dichloromethane/methanol, 10:1); MS (ESI) $\mathrm{m} / \mathrm{z}$ calculated for $\mathrm{C}_{40} \mathrm{H}_{75} \mathrm{~N}_{2} \mathrm{O}_{13}$ 791.5269; found $\left(\mathrm{M}+\mathrm{H}^{+}\right)$791.5278.

To a solution of the acetate product $(1.5 \mathrm{~g}, 1.90 \mathrm{mmol})$ in toluene $(20 \mathrm{ml})$ was added $\mathrm{Et}_{3} \mathrm{~N}(0.60 \mathrm{ml}, 4.33 \mathrm{mmol})$ and $1,1^{\prime}$-carbonyldiimidazole $(1.34 \mathrm{~g}$, $7.60 \mathrm{mmol}$ ). The resulting solution was stirred at $55^{\circ} \mathrm{C}$ for $48 \mathrm{~h}$. The reaction was concentrated in vacuo and the residue was dissolved with dichloromethane $(20 \mathrm{ml})$, which was quenched with saturated $\mathrm{NaHCO}_{3}(20 \mathrm{ml})$, and the aqueous layer was extracted with dichloromethane $(3 \times 10 \mathrm{ml})$. The combined organic layers were dried over anhydrous $\mathrm{Na}_{2} \mathrm{SO}_{4}$, filtered and concentrated in vacuo. The residue was purified by flash chromatography (dichloromethane/methanol, 20:1) to afford $1.50 \mathrm{~g}(86.6 \%)$ of 2 as a white solid: m.p. $117-120^{\circ} \mathrm{C} ; \mathrm{R}_{\mathrm{f}}=0.61$ (dichloromethane/methanol, 10:1). MS (ESI) $\mathrm{m} / \mathrm{z}$ calculated for $\mathrm{C}_{45} \mathrm{H}_{75} \mathrm{~N}_{4} \mathrm{O}_{15}$ 911.5229; found $\left(\mathrm{M}+\mathrm{H}^{+}\right)$911.5219.

\section{2'-O-acetyl-4" $-O$-aminoalkyl carbamoyl AZM 11,12-carbonate (3) or $(4)$}

To a solution of $2(1.5 \mathrm{~g}, 1.65 \mathrm{mmol})$ in DMF $(15 \mathrm{ml})$ was added 1,8 diazabicyclo(5.4.0)undec-7-ene $(0.33 \mathrm{ml}, 2.25 \mathrm{mmol})$ and ethylenediamine $(3.3 \mathrm{mmol})$ or 1,4 -butanediamine hydrochloride $(3.3 \mathrm{mmol})$. The resulting solution was stirred for $4 \mathrm{~h}$ at room temperature. The reaction was quenched with $5 \%$ aqueous $\mathrm{NaHCO}_{3}(20 \mathrm{ml})$ and the aqueous layer was extracted with ethyl acetate $(2 \times 15 \mathrm{ml})$. The combined organic layers were washed with brine and dried over anhydrous $\mathrm{Na}_{2} \mathrm{SO}_{4}$, filtered. The filtrate was concentrated in vacuo to afford a crude product of $4^{\prime \prime}-O$-(2-aminoethyl)carbamate 3 or $4^{\prime \prime}-O$ (4-aminobutyl)carbamate $\mathbf{4}$ in yield of about $93.2 \%$.

\section{General methods for $4^{\prime \prime}$-O-(benzamido)alkyl carbamates of 11,12-cyclic carbonate AZM (5a-g or $6 \mathrm{a}-\mathrm{g})$}

The solution of the corresponding substituted benzoic acid (1 eq.) and 1hydroxybenzotriazole (1.1 eq.) in tetrahydrofuran $(15 \mathrm{ml})$ was added $1,3-$ dicyclohexylcarbodiimide ( 1.1 eq.) at $0^{\circ} \mathrm{C}$ and stirred for $0.5-1 \mathrm{~h}$ at the same temperature. Then the $4^{\prime \prime}$-O-aminoalkyl carbamates 3 (or 4 ) was added, the resulting solution was stirred for another $2 \mathrm{~h}$ at room temperature.

The reaction was concentrated in vacuo and ethyl acetate $(15 \mathrm{ml})$ was added. After stirring for $1 \mathrm{~h}$, the insoluble substance was filtered out. The filtrate was quenched with $5 \%$ aqueous $\mathrm{NaHCO}_{3}(20 \mathrm{ml})$ and the aqueous layer was extracted with ethyl acetate $(2 \times 15 \mathrm{ml})$. The combined organic layers were washed with brine, dried over anhydrous $\mathrm{Na}_{2} \mathrm{SO}_{4}$ and filtered. The filtrate was concentrated in vacuo to afford a crude product in $85.7-90.2 \%$ yield.

A solution of the above crude product in methanol $(15 \mathrm{ml})$ was heated to $55^{\circ} \mathrm{C}$ and stirred for $12 \mathrm{~h}$ at the same temperature. After concentrating the reaction solution in vacuo, the residue was purified by flash chromatography (dichloromethane/methanol, 30:1) to give the desired products $\mathbf{5 a}-\mathbf{g}$ (or $\mathbf{6 a}-\mathbf{g}$ ) in yields ranging from 75.8 to $87.6 \%$.

\section{4" $-O-(((4-M e t h o x y b e n z a m i d o) e t h y l)$ carbamoyl $)$}

\section{AZM-11,12-carbonate (5a)}

White solid, yield $82.9 \%$, m.p. $158-161{ }^{\circ} \mathrm{C}$, TLC $\mathrm{R}_{\mathrm{f}}=0.36$ (methanol/dichlormethane, 1:10); IR (KBr): 3416, 2973, 2937, 2880, 2830, 2788, 1813, 1727, 1654, $1613,1534,1505,1457,1379,1353,1334,1302,1276,1256,1235,1166,1110$, 1073,1046 and $1015 \mathrm{~cm}^{-1} ;{ }^{1} \mathrm{H}$ NMR $\left(600 \mathrm{MHz}, \mathrm{CDCl}_{3}, \delta\right.$ p.p.m.) 7.77 (d, $2 \mathrm{H}$, $J=8.4 \mathrm{~Hz}), 6.90(\mathrm{~d}, 2 \mathrm{H}, J=9.0 \mathrm{~Hz}), 5.01(\mathrm{~d}, 1 \mathrm{H}, J=4.2 \mathrm{~Hz}), 4.88(\mathrm{dd}, 1 \mathrm{H}$, $J=9.6 \mathrm{~Hz}, J=6.6 \mathrm{~Hz}), 4.56-4.46(\mathrm{~m}, 2 \mathrm{H}), 4.36-4.24(\mathrm{~m}, 2 \mathrm{H}), 3.85(\mathrm{~s}, 3 \mathrm{H}), 3.70-$ $3.64(\mathrm{~m}, 1 \mathrm{H}), 3.64-3.52(\mathrm{~m}, 3 \mathrm{H}), 3.52-3.42(\mathrm{~m}, 2 \mathrm{H}), 3.40-3.32(\mathrm{~m}, 2 \mathrm{H}), 3.27$ (s, 3H), 2.88-2.78 (m, 2H), $2.59(\mathrm{~s}, 6 \mathrm{H}), 2.44-2.40(\mathrm{~m}, 2 \mathrm{H}), 2.36-2.30(\mathrm{~m}, 2 \mathrm{H})$, $2.20(\mathrm{~s}, 3 \mathrm{H}), 2.30-2.20(\mathrm{~m}, 1 \mathrm{H}), 1.94-1.88(\mathrm{~m}, 1 \mathrm{H}), 1.86-1.78(\mathrm{~m}, 2 \mathrm{H}), 1.66-$ $1.50(\mathrm{~m}, 2 \mathrm{H}), 1.44(\mathrm{~s}, 3 \mathrm{H}), 1.38-1.24(\mathrm{~m}, 6 \mathrm{H}), 1.22-1.16(\mathrm{~m}, 6 \mathrm{H}), 1.14-1.10$ $(\mathrm{m}, 3 \mathrm{H}), 1.10-1.04(\mathrm{~m}, 6 \mathrm{H}), 1.02-0.98(\mathrm{~m}, 3 \mathrm{H})$ and $0.96-0.88(\mathrm{~m}, 6 \mathrm{H})$; HRMS (ESI) $\mathrm{m} / \mathrm{z}$ calculated for $\mathrm{C}_{50} \mathrm{H}_{83} \mathrm{~N}_{4} \mathrm{O}_{16}\left(\mathrm{M}+\mathrm{H}^{+}\right)$995.5804, found 995.5810 .

\section{$4^{\prime \prime}-O-(((2-M e t h o x y b e n z a m i d o) e t h y l)$ carbamoyl $)$ AZM-11,12-carbonate (5b)}

White solid, yield $85.3 \%$, m.p. $160-162{ }^{\circ} \mathrm{C}$, TLC $\mathrm{R}_{\mathrm{f}}=0.40$ (methanol/dichlormethane, 1:10); IR (KBr): 3400, 3075, 2972, 2936, 2880, 1812, 1721, 1648, $1600,1532,1484,1463,1383,1336,1301,1238,1166,1108,1085,1045$ and $1015 \mathrm{~cm}^{-1}$; ${ }^{1} \mathrm{H}$ NMR $\left(600 \mathrm{MHz}, \mathrm{CDCl}_{3}, \delta\right.$ p.p.m.) 7.80 (d, $\left.1 \mathrm{H}, J=7.8 \mathrm{~Hz}\right), 7.61$ $(\mathrm{d}, 1 \mathrm{H}, J=7.8 \mathrm{~Hz}), 7.43(\mathrm{t}, 1 \mathrm{H}, J=7.8 \mathrm{~Hz}), 7.04(\mathrm{t}, 1 \mathrm{H}, J=7.8 \mathrm{~Hz}), 5.01(\mathrm{~d}, 1 \mathrm{H}$, $J=4.2 \mathrm{~Hz}), 4.86(\mathrm{dd}, 1 \mathrm{H}, J=9.0 \mathrm{~Hz}, J=6.0 \mathrm{~Hz}), 4.58-4.48(\mathrm{~m}, 2 \mathrm{H}), 4.34-4.22$ (m, $2 \mathrm{H}), 3.96(\mathrm{~s}, 3 \mathrm{H}), 3.78-3.70(\mathrm{~m}, 1 \mathrm{H}), 3.66-3.54(\mathrm{~m}, 3 \mathrm{H}), 3.54-3.42(\mathrm{~m}$, $4 \mathrm{H}), 3.30(\mathrm{~s}, 3 \mathrm{H}), 2.88-2.70(\mathrm{~m}, 9 \mathrm{H}), 2.46-2.40(\mathrm{~d}, 1 \mathrm{H}, J=10.2 \mathrm{~Hz}), 2.36-2.30$ $(\mathrm{d}, 1 \mathrm{H}, J=9.0 \mathrm{~Hz}), 2.24-2.10(\mathrm{~m}, 5 \mathrm{H}), 2.04-2.00(\mathrm{~m}, 1 \mathrm{H}), 1.90-1.80(\mathrm{~m}, 2 \mathrm{H})$, $1.62-1.58(\mathrm{~m}, 5 \mathrm{HH}), 1.46-1.40(\mathrm{~m}, 2 \mathrm{H}), 1.28-1.22(\mathrm{~m}, 7 \mathrm{H}), 1.22-1.14(\mathrm{~m}$, $6 \mathrm{H}), 1.14-1.10(\mathrm{~m}, 3 \mathrm{H}), 1.10-1.02(\mathrm{~m}, 3 \mathrm{H}), 1.02-0.96(\mathrm{~m}, 3 \mathrm{H}), 0.96-0.84(\mathrm{~m}$, $6 \mathrm{H}$ ); HRMS (ESI) $\mathrm{m} / \mathrm{z}$ calculated for $\mathrm{C}_{50} \mathrm{H}_{83} \mathrm{~N}_{4} \mathrm{O}_{16}\left(\mathrm{M}+\mathrm{H}^{+}\right)$995.5804, found 995.5779 .

\section{$4^{\prime \prime}$-O-(( (3,4-dimethoxybenzamido)ethyl)carbamoyl $)$ AZM-11,12-carbonate $(5 \mathrm{c})$}

White solid, yield $83.7 \%$, m.p. $159-162{ }^{\circ} \mathrm{C}$, TLC $\mathrm{R}_{\mathrm{f}}=0.37$ (methanol/dichlormethane, 1:10); IR (KBr): 3411, 3083, 2972, 2937, 2879, 2836, 1812, 1726, 1647, 1604, 1584, 1507, 1459, 1383, 1353, 1311, 1269, 1232, 1166, 1110, 1074, 1045 and $1016 \mathrm{~cm}^{-1}$; ${ }^{1} \mathrm{H} \mathrm{NMR}\left(600 \mathrm{MHz}, \mathrm{CDCl}_{3}, \delta\right.$ p.p.m. $) 7.45(\mathrm{~d}, 1 \mathrm{H}, J=1.8 \mathrm{~Hz})$, $7.32(\mathrm{dd}, 1 \mathrm{H}, J=8.4 \mathrm{~Hz}, J=6.6 \mathrm{~Hz}), 7.04-6.98(\mathrm{~m}, 1 \mathrm{H}), 5.07(\mathrm{~d}, 1 \mathrm{H}, J=4.8 \mathrm{~Hz})$, $4.88(\mathrm{dd}, 1 \mathrm{H}, J=9.6 \mathrm{~Hz}, J=6.6 \mathrm{~Hz}), 4.53(\mathrm{~d}, 1 \mathrm{H}, J=9.6 \mathrm{~Hz}) 4.46-4.30(\mathrm{~m}, 3 \mathrm{H})$, 3.96-3.90 (m, 6H), 3.70-3.60 (m, 3H), 3.60-3.44 (m, 5H), $3.28(\mathrm{~s}, 3 \mathrm{H}), 2.90-$ $2.82(\mathrm{~m}, 2 \mathrm{H}), 2.74-2.64(\mathrm{~m}, 1 \mathrm{H}), 2.46-2.30(\mathrm{~m}, 8 \mathrm{H}), 2.24-2.16(\mathrm{~m}, 4 \mathrm{H}), 2.08-$ $2.02(\mathrm{~m}, 2 \mathrm{H}), 1.88-1.74(\mathrm{~m}, 2 \mathrm{H}), 1.64-1.58(\mathrm{~m}, 3 \mathrm{H}), 1.48-1.38(\mathrm{~m}, 4 \mathrm{H}), 1.30$ $1.22(\mathrm{~m}, 6 \mathrm{H}), 1.22-1.12(\mathrm{~m}, 7 \mathrm{H}), 1.12-1.00(\mathrm{~m}, 9 \mathrm{H})$ and $0.96-0.86(\mathrm{~m}, 6 \mathrm{H})$; HRMS (ESI) $\mathrm{m} / \mathrm{z}$ calculated for $\mathrm{C}_{51} \mathrm{H}_{85} \mathrm{~N}_{4} \mathrm{O}_{17}\left(\mathrm{M}+\mathrm{H}^{+}\right)$1025.5910, found 1025.5896

\section{$4^{\prime \prime}$-O-((4-chlorobenzamido)ethyl)carbamoyl) \\ AZM-11,12-carbonate (5d)}

White solid, yield $87.6 \%$, m.p. $163-165^{\circ} \mathrm{C}$, TLC $\mathrm{R}_{\mathrm{f}}=0.36$ (methanol/dichlormethane, 1:10); IR (KBr): 3384, 3068, 2973, 2937, 2879, 1812, 1726, 1656, 1596, 1532, 1486, 1459, 1382, 1353, 1335, 1314, 1256, 1236, 1167, 1110, 1074, 1045 and $1014 \mathrm{~cm}^{-1}$; ${ }^{1} \mathrm{H}$ NMR $\left(600 \mathrm{MHz}, \mathrm{CDCl}_{3}, \delta\right.$ p.p.m. $) 7.79(\mathrm{~d}, 2 \mathrm{H}, J=8.4 \mathrm{~Hz})$, $7.39(\mathrm{~d}, 2 \mathrm{H}, J=7.8 \mathrm{~Hz}), 5.05(\mathrm{~d}, 1 \mathrm{H}, J=4.8 \mathrm{~Hz}), 4.90(\mathrm{dd}, 1 \mathrm{H}, J=9.6 \mathrm{~Hz}$, $J=6.6 \mathrm{~Hz}), 4.54(\mathrm{~d}, 1 \mathrm{H}, J=9.6 \mathrm{~Hz}), 4.49(\mathrm{~d}, 1 \mathrm{H}, J=7.2 \mathrm{~Hz}), 4.36-4.26(\mathrm{~m}$, $2 \mathrm{H}), 3.70-3.52(\mathrm{~m}, 4 \mathrm{H}), 3.52-3.44(\mathrm{~m}, 3 \mathrm{H}), 3.38-3.36(\mathrm{~m}, 1 \mathrm{H}), 3.17(\mathrm{~s}, 3 \mathrm{H})$, 2.88-2.78 (m, $2 \mathrm{H}), 2.62-2.50(\mathrm{~m}, 7 \mathrm{H}), 2.46-2.40(\mathrm{~m}, 1 \mathrm{H}), 2.36-2.30(\mathrm{~m}, 1 \mathrm{H})$, $2.22(\mathrm{~s}, 3 \mathrm{H}), 2.04-2.00(\mathrm{~m}, 1 \mathrm{H}), 1.94-1.88(\mathrm{~m}, 1 \mathrm{H}), 1.86-1.78(\mathrm{~m}, 2 \mathrm{H}), 1.64-$ $1.52(\mathrm{~m}, 3 \mathrm{H}), 1.44(\mathrm{~s}, 3 \mathrm{H}), 1.42-1.24(\mathrm{~m}, 7 \mathrm{H}), 1.22-1.16(\mathrm{~m}, 6 \mathrm{H}), 1.14-1.10$ $(\mathrm{m}, 3 \mathrm{H}), 1.10-1.04(\mathrm{~m}, 6 \mathrm{H}), 1.04-0.98(\mathrm{~m}, 3 \mathrm{H})$ and $0.96-0.88(\mathrm{~m}, 6 \mathrm{H})$; HRMS (ESI) $\mathrm{m} / \mathrm{z}$ calculated for $\mathrm{C}_{49} \mathrm{H}_{80} \mathrm{ClN}_{4} \mathrm{O}_{15}\left(\mathrm{M}+\mathrm{H}^{+}\right)$999.5309, found 999.5277 .

\section{4" $-O-(((2,4-$ dichlorobenzamido)ethyl)carbamoyl $)$}

\section{AZM-11,12-carbonate (5e)}

White solid, yield $80.2 \%$, m.p. $165-168^{\circ} \mathrm{C}$, TLC $\mathrm{R}_{\mathrm{f}}=0.37$ (methanol/dichlormethane, 1:10); IR (KBr): 3431, 3088, 2971, 2933, 1814, 1728, 1664, 1589, 1518, 
$1459,1379,1353,1334,1301,1235,1166,1108,1087,1073,1045$ and $1014 \mathrm{~cm}^{-1}$; ${ }^{1} \mathrm{H}$ NMR $\left(600 \mathrm{MHz}, \mathrm{CDCl}_{3}, \delta\right.$ p.p.m.) 7.58 (d, $\left.1 \mathrm{H}, J=8.4 \mathrm{~Hz}\right), 7.41$ (d, $1 \mathrm{H}$, $J=1.8 \mathrm{~Hz}), 7.30(\mathrm{dd}, 1 \mathrm{H}, J=8.4 \mathrm{~Hz}, J=6.6 \mathrm{~Hz}), 5.07(\mathrm{~d}, 1 \mathrm{H}, J=4.2 \mathrm{~Hz}), 4.88(\mathrm{dd}$, $1 \mathrm{H}, J=9.0 \mathrm{~Hz}, J=6.0 \mathrm{~Hz}), 4.52(\mathrm{~d}, 1 \mathrm{H}, J=10.2 \mathrm{~Hz}), 4.46-4.30(\mathrm{~m}, 3 \mathrm{H}), 3.70-3.60$ (m, $2 \mathrm{H}), 3.60-3.54(\mathrm{~m}, 3 \mathrm{H}), 3.52-3.42(\mathrm{~m}, 3 \mathrm{H}), 3.32(\mathrm{~s}, 3 \mathrm{H}), 2.92-2.80(\mathrm{~m}, 2 \mathrm{H})$, 2.62-2.58 (m, 1H), 2.42-2.40 (m, 1H), 2.38-2.26 (m, 7H), 2.22-2.16 (s, $4 \mathrm{H})$, 2.08-2.02 (m, 1H), 1.96-1.88 (m, 1H), 1.86-1.66 (m, 4H), 1.64-1.54 (m, 2H), $1.44(\mathrm{~s}, 3 \mathrm{H}), 1.32-1.22(\mathrm{~m}, 7 \mathrm{H}), 1.22-1.16(\mathrm{~m}, 6 \mathrm{H}), 1.12-1.08(\mathrm{~m}, 3 \mathrm{H}), 1.08-$ $1.00(\mathrm{~m}, 3 \mathrm{H})$ and $0.96-0.80(\mathrm{~m}, 9 \mathrm{H})$; HRMS (ESI) $\mathrm{m} / \mathrm{z}$ calculated for $\mathrm{C}_{49} \mathrm{H}_{79} \mathrm{Cl}_{2} \mathrm{~N}_{4} \mathrm{O}_{15}\left(\mathrm{M}+\mathrm{H}^{+}\right)$1033.4919, found 1033.4889.

\section{$4^{\prime \prime}$-O-((4-nitrobenzamido)ethyl)carbamoyl) \\ AZM-11,12-carbonate (5f)}

White solid, yield $85.7 \%$, m.p. $130-132^{\circ} \mathrm{C}$, TLC $\mathrm{R}_{\mathrm{f}}=0.39$ (methanol/dichlormethane, 1:10); IR (KBr): 3397, 3070, 2973, 2937, 2880, 1812, 1727, 1665, 1601, $1527,1488,1459,1382,1348,1300,1256,1236,1167,1109,1074,1045$ and $1014 \mathrm{~cm}^{-1}$; ${ }^{1} \mathrm{H}$ NMR $\left(600 \mathrm{MHz}, \mathrm{CDCl}_{3}, \delta\right.$ p.p.m.) 8.27 (dd, $2 \mathrm{H}, J=9.0 \mathrm{~Hz}$, $J=6.6 \mathrm{~Hz}), 8.07(\mathrm{~d}, 2 \mathrm{H}, J=8.4 \mathrm{~Hz}), 5.05(\mathrm{~d}, 1 \mathrm{H}, J=4.2 \mathrm{~Hz}), 4.90(\mathrm{dd}, 1 \mathrm{H}$, $J=9.0 \mathrm{~Hz}, J=6.0 \mathrm{~Hz}), 4.58-4.50(\mathrm{~m}, 1 \mathrm{H}), 4.42-4.38(\mathrm{~s}, 1 \mathrm{H}), 4.34-4.26(\mathrm{~m}, 2 \mathrm{H})$, 3.74-3.58 (m, 4H), 3.58-3.44 (m, 4H), 3.44-3.38 (m, $2 \mathrm{H}), 3.27(\mathrm{~s}, 3 \mathrm{H}), 2.86-$ $2.74(\mathrm{~m}, 3 \mathrm{H}), 2.60-2.54(\mathrm{~s}, 7 \mathrm{H}), 2.46-2.42(\mathrm{~m}, 1 \mathrm{H}), 2.36-2.28(\mathrm{~m}, 2 \mathrm{H}), 2.21(\mathrm{~s}$, $3 \mathrm{H}), 2.18-2.08(\mathrm{~m}, 2 \mathrm{H}), 2.08-1.90(\mathrm{~m}, 3 \mathrm{H}), 1.86-1.78(\mathrm{~m}, 2 \mathrm{H}), 1.54-1.66(\mathrm{~m}$, $2 \mathrm{H}), 1.44(\mathrm{~s}, 3 \mathrm{H}),, 1.38-1.30(\mathrm{~m}, 1 \mathrm{H}), 1.27(\mathrm{~s}, 3 \mathrm{H}), 1.22-1.16(\mathrm{~m}, 2 \mathrm{H}), 1.16-$ $1.12(\mathrm{~m}, 3 \mathrm{H}), 1.10-1.04(\mathrm{~m}, 6 \mathrm{H}), 1.04-0.98(\mathrm{~m}, 3 \mathrm{H})$ and $0.96-0.88(\mathrm{~m}, 6 \mathrm{H})$; HRMS (ESI) $\mathrm{m} / \mathrm{z}$ calculated for $\mathrm{C}_{49} \mathrm{H}_{80} \mathrm{~N}_{5} \mathrm{O}_{17}\left(\mathrm{M}+\mathrm{H}^{+}\right)$1010.5549, found 1010.5528 .

\section{$4^{\prime \prime}-O-(((3,5-$ dinitrobenzamido $)$ ethyl $)$ carbamoyl $)$ \\ AZM-11,12-carbonate (5g)}

Slightly yellow solid, yield $75.8 \%$, m.p. $129-131{ }^{\circ} \mathrm{C}$, TLC $\mathrm{R}_{\mathrm{f}}=0.30$ (methanol/ dichlormethane, 1:10); IR (KBr): 3431, 3104, 2973, 2937, 2880, 1812, 1729, 1672, 1629, 1544, 1458, 1382, 1344, 1304, 1258, 1236, 1167, 1111, 1074, 1045 and $10145 \mathrm{~cm}^{-1}$; ${ }^{1} \mathrm{H}$ NMR $\left(600 \mathrm{MHz}, \mathrm{CDCl}_{3}, \delta\right.$ p.p.m. $) 9.15(\mathrm{t}, 1 \mathrm{H}, J=7.8 \mathrm{~Hz})$, $9.05(\mathrm{~d}, 1 \mathrm{H}, J=1.2 \mathrm{~Hz}), 7.30(\mathrm{dd}, 1 \mathrm{H}, J=8.4 \mathrm{~Hz}, J=6.6 \mathrm{~Hz}), 5.09(\mathrm{~d}, 1 \mathrm{H}$, $J=4.8 \mathrm{~Hz}), 4.89(\mathrm{dd}, 1 \mathrm{H}, J=9.6 \mathrm{~Hz}, J=6.6 \mathrm{~Hz}), 4.61(\mathrm{~d}, 1 \mathrm{H}, J=9.6 \mathrm{~Hz}), 4.46-$ $4.34(\mathrm{~m}, 3 \mathrm{H}), 3.70-3.64(\mathrm{~m}, 2 \mathrm{H}), 3.64-3.46(\mathrm{~m}, 5 \mathrm{H}), 3.30(\mathrm{~s}, 4 \mathrm{H}), 2.94-2.88$ $(\mathrm{m}, 1 \mathrm{H}), 2.88-2.80(\mathrm{~m}, 1 \mathrm{H}), 2.70-2.60(\mathrm{~s}, 1 \mathrm{H}), 2.40-2.43(\mathrm{~m}, 8 \mathrm{H}), 2.19(\mathrm{~s}, 3 \mathrm{H})$, $2.08-2.02(\mathrm{~m}, 1 \mathrm{H}), 1.84-1.74(\mathrm{~m}, 2 \mathrm{H}), 1.70-1.62(\mathrm{~m}, 2 \mathrm{H}), 1.62-1.50(\mathrm{~m}, 2 \mathrm{H})$, $1.44(\mathrm{~s}, 3 \mathrm{H}), 1.30-1.20(\mathrm{~m}, 7 \mathrm{H}), 1.22-1.16(\mathrm{~m}, 6 \mathrm{H}), 1.12-1.08(\mathrm{~m}, 3 \mathrm{H}), 1.10$ $1.02(\mathrm{~m}, 5 \mathrm{H})$ and $0.96-0.82(\mathrm{~m}, 9 \mathrm{H})$; HRMS (ESI) $\mathrm{m} / \mathrm{z}$ calculated for $\mathrm{C}_{49} \mathrm{H}_{79} \mathrm{~N}_{6} \mathrm{O}_{19}\left(\mathrm{M}+\mathrm{H}^{+}\right)$1055.5400, found 1055.5387 .

\section{4"-O-((4-methoxybenzamido)butyl)carbamoyl $)$ \\ AZM-11,12-carbonate (6a)}

White solid, yield $86.8 \%$, m.p. $163-166^{\circ} \mathrm{C}$, TLC $\mathrm{R}_{\mathrm{f}}=0.35$ (methanol/dichlormethane, 1:10); IR (KBr): 3419, 3076, 2972, 2936, 2877, 1812, 1723, 1643, 1607, $1575,1540,1505,1458,1382,1353,1300,1254,1169,1109,1074,1044$ and $1015 \mathrm{~cm}^{-1} ;{ }^{1} \mathrm{H}$ NMR $\left(600 \mathrm{MHz}, \mathrm{CDCl}_{3}, \delta\right.$ p.p.m. $) 7.75(\mathrm{~d}, 2 \mathrm{H}, J=9.0 \mathrm{~Hz}), 6.92$ $(\mathrm{d}, 2 \mathrm{H}, J=9.6 \mathrm{~Hz}), 5.07(\mathrm{~d}, 1 \mathrm{H}, J=4.8 \mathrm{~Hz}), 4.89(\mathrm{dd}, 1 \mathrm{H}), 4.54(\mathrm{~d}, 1 \mathrm{H}$, $J=10.2 \mathrm{~Hz}), 4.42-4.30(\mathrm{~m}, 3 \mathrm{H}), 3.85(\mathrm{~s}, 3 \mathrm{H}), 3.70-3.58(\mathrm{~m}, 2 \mathrm{H}), 3.50-3.44$ $(\mathrm{m}, 2 \mathrm{H}), 3.36-3.30(\mathrm{~m}, 5 \mathrm{H}), 3.30-3.20(\mathrm{~m}, 2 \mathrm{H}), 2.90-2.82(\mathrm{~m}, 2 \mathrm{H}), 2.82-2.78$ (m, $1 \mathrm{H}), 2.48-2.38(\mathrm{~m}, 7 \mathrm{H}), 2.38-2.32(\mathrm{~m}, 1 \mathrm{H}), 2.21(\mathrm{~s}, 4 \mathrm{H}), 2.06-2.02(\mathrm{~m}$, $1 \mathrm{H}), 1.96-1.88(\mathrm{~m}, 1 \mathrm{H}), 1.86-1.80(\mathrm{~m}, 1 \mathrm{H}), 1.70-1.50(\mathrm{~m}, 7 \mathrm{H}), 1.48-1.40(\mathrm{~m}$, $5 \mathrm{H}), 1.32-1.24(\mathrm{~m}, 6 \mathrm{H}), 1.23-1.18(\mathrm{~m}, 10 \mathrm{H}), 1.14(\mathrm{~s}, 3 \mathrm{H}), 1.10-1.02(\mathrm{~m}, 6 \mathrm{H})$ and $0.96-0.88(\mathrm{~m}, 3 \mathrm{H})$; HRMS (ESI) $\mathrm{m} / \mathrm{z}$ calculated for $\mathrm{C}_{52} \mathrm{H}_{87} \mathrm{~N}_{4} \mathrm{O}_{16}\left(\mathrm{M}+\mathrm{H}^{+}\right)$ 1023.6117, found 1023.6095.

\section{4"-O-(((2-methoxybenzamido)butyl)carbamoyl $)$}

\section{AZM-11,12-carbonate (6b)}

White solid, yield $83.2 \%$, m.p. $166-168^{\circ} \mathrm{C}$, TLC $\mathrm{R}_{\mathrm{f}}=0.38$ (methanol/dichlormethane, 1:10); IR (KBr): 3407, 3077, 2972, 2937, 2877, 1812, 1721, 1649, 1600, $1536,1484,1458,1383,1353,1334,1299,1278,1238,1166,1109,1085,1074$, 1046 and $1015 \mathrm{~cm}^{-1} ;{ }^{1} \mathrm{H}$ NMR $\left(600 \mathrm{MHz}, \mathrm{CDCl}_{3}, \delta\right.$ p.p.m.) 7.98-7.86 (m, $\left.1 \mathrm{H}\right)$, $7.45(\mathrm{t}, 1 \mathrm{H}, J=7.8 \mathrm{~Hz}), 7.08(\mathrm{t}, 1 \mathrm{H}, J=7.8 \mathrm{~Hz}), 6.98(\mathrm{~d}, 1 \mathrm{H}, J=7.2 \mathrm{~Hz}), 5.06(\mathrm{~d}$, $1 \mathrm{H}, J=3.0 \mathrm{~Hz}), 4.88(\mathrm{dd}, 1 \mathrm{H}, J=9.0 \mathrm{~Hz}, J=6.0 \mathrm{~Hz}), 4.55(\mathrm{~d}, 1 \mathrm{H}, J=9.6 \mathrm{~Hz})$, $4.42-4.30(\mathrm{~m}, 3 \mathrm{H}), 3.97(\mathrm{~s}, 3 \mathrm{H}), 3.68-3.62(\mathrm{~m}, 1 \mathrm{H}), 3.62-3.56(\mathrm{~m}, 1 \mathrm{H}), 3.52-$ $3.44(\mathrm{~m}, 2 \mathrm{H}), 3.36-3.20(\mathrm{~m}, 7 \mathrm{H}), 2.90-2.76(\mathrm{~m}, 3 \mathrm{H}), 2.50-2.30(\mathrm{~m}, 8 \mathrm{H}), 2.19$ (s, $4 \mathrm{H}), 2.06-2.04(\mathrm{~m}, 1 \mathrm{H}), 1.96-1.88(\mathrm{~m}, 1 \mathrm{H}), 1.88-1.78(\mathrm{~m}, 3 \mathrm{H}), 1.68-1.56$ $(\mathrm{m}, 6 \mathrm{H}), 1.44(\mathrm{~s}, 4 \mathrm{H}), 1.32-1.24(\mathrm{~m}, 7 \mathrm{H}), 1.22-1.16(\mathrm{~m}, 9 \mathrm{H}), 1.15(\mathrm{~s}, 3 \mathrm{H})$, $1.10-1.02(\mathrm{~m}, 6 \mathrm{H})$ and $0.96-0.86(\mathrm{~m}, 3 \mathrm{H})$; HRMS (ESI) $\mathrm{m} / \mathrm{z}$ calculated for $\mathrm{C}_{52} \mathrm{H}_{87} \mathrm{~N}_{4} \mathrm{O}_{16}\left(\mathrm{M}+\mathrm{H}^{+}\right)$1023.6117, found 1023.6085.

\section{$4^{\prime \prime}$-O-(((3,4-dimethoxybenzamido)butyl)carbamoyl $)$ AZM-11,12-carbonate (6c)}

White solid, yield $79.9 \%$, m.p. $165-167^{\circ} \mathrm{C}$, TLC $\mathrm{R}_{\mathrm{f}}=0.34$ (methanol/dichlormethane, 1:10); IR (KBr): 3403, 3083, 2972, 2936, 2872, 1812, 1724, 1644, 1603, $1584,1540,1507,1458,1382,1352,1336,1306,1269,1232,1167,1126,1110$, 1074,1045 and $1016 \mathrm{~cm}^{-1} ;{ }^{1} \mathrm{H}$ NMR $\left(600 \mathrm{MHz}, \mathrm{CDCl}_{3}, \delta\right.$ p.p.m.) $7.44(\mathrm{~d}, 1 \mathrm{H}$, $J=1.8 \mathrm{~Hz}), 7.21(\mathrm{~d}, 1 \mathrm{H}, J=7.8 \mathrm{~Hz}), 6.86(\mathrm{~d}, 1 \mathrm{H}, J=8.4 \mathrm{~Hz}), 5.06(\mathrm{~d}, 1 \mathrm{H}$, $J=3.6 \mathrm{~Hz}), 4.89(\mathrm{dd}, 1 \mathrm{H}, J=9.6 \mathrm{~Hz}, J=6.0 \mathrm{~Hz}), 4.55(\mathrm{~d}, 1 \mathrm{H}, J=9.6 \mathrm{~Hz}), 4.42-$ $4.32(\mathrm{~m}, 3 \mathrm{H}), 3.76-3.70(\mathrm{~m}, 6 \mathrm{H}), 3.68-3.56(\mathrm{~m}, 2 \mathrm{H}), 3.52-3.44(\mathrm{~m}, 2 \mathrm{H}), 3.36-$ $3.22(\mathrm{~m}, 7 \mathrm{H}), 2.90-2.72(\mathrm{~m}, 3 \mathrm{H}), 2.50-2.30(\mathrm{~m}, 8 \mathrm{H}), 2.20(\mathrm{~s}, 4 \mathrm{H}), 2.06-2.02$ $(\mathrm{m}, 1 \mathrm{H}), 1.96-1.88(\mathrm{~m}, 1 \mathrm{H}), 1.86-1.80(\mathrm{~m}, 1 \mathrm{H}), 1.76-1.50(\mathrm{~m}, 9 \mathrm{H}), 1.48-1.40$ $(\mathrm{m}, 3 \mathrm{H}), 1.32-1.24(\mathrm{~m}, 6 \mathrm{H}), 1.24-1.18(\mathrm{~m}, 10 \mathrm{H}), 1.15(\mathrm{~s}, 3 \mathrm{H}), 1.10-1.00(\mathrm{~m}$, $6 \mathrm{H})$ and $0.94-0.90(\mathrm{~m}, 3 \mathrm{H})$; HRMS (ESI) $\mathrm{m} / \mathrm{z}$ calculated for $\mathrm{C}_{53} \mathrm{H}_{89} \mathrm{~N}_{4} \mathrm{O}_{17}$ $\left(\mathrm{M}+\mathrm{H}^{+}\right)$1053.6223, found 1053.6183.

\section{$4^{\prime \prime}-O-(((4-c h l o r o b e n z a m i d o) b u t y l)$ carbamoyl $)$ \\ AZM-11,12-carbonate (6d)}

White solid, yield $80.5 \%$, m.p. $158-161^{\circ} \mathrm{C}$, TLC $\mathrm{R}_{\mathrm{f}}=0.40$ (methanol/dichlormethane, 1:10); IR (KBr): 3412, 3068, 2972, 2936, 2877, 1812, 1724, 1649, 1596, 1536, 1486, 1457, 1383, 1353, 1314, 1275, 1237, 1167, 1109, 1090, 1074, 1045 and $1014 \mathrm{~cm}^{-1}$; ${ }^{1} \mathrm{H}$ NMR $\left(600 \mathrm{MHz}, \mathrm{CDCl}_{3}, \delta\right.$ p.p.m. $) 7.76(\mathrm{~d}, 2 \mathrm{H}, J=6.0 \mathrm{~Hz})$, $7.39(\mathrm{~d}, 2 \mathrm{H}, J=8.4 \mathrm{~Hz}), 5.06(\mathrm{~d}, 1 \mathrm{H}, J=4.2 \mathrm{~Hz}), 4.89(\mathrm{dd}, 1 \mathrm{H}, J=9.6 \mathrm{~Hz}$, $J=6.6 \mathrm{~Hz}), 4.58-4.50(\mathrm{~m}, 1 \mathrm{H}), 4.42-4.30(\mathrm{~m}, 3 \mathrm{H}), 3.72-3.62(\mathrm{~m}, 1 \mathrm{H}), 3.62-$ $3.54(\mathrm{~m}, 1 \mathrm{H}), 3.52-3.40(\mathrm{~m}, 2 \mathrm{H}), 3.30(\mathrm{~s}, 3 \mathrm{H}), 3.28-3.20(\mathrm{~m}, 4 \mathrm{H}), 2.94-2.86$ $(\mathrm{m}, 3 \mathrm{H}), 2.54-2.46(\mathrm{~s}, 6 \mathrm{H}), 2.46-2.32(\mathrm{~m}, 3 \mathrm{H}), 2.20(\mathrm{~s}, 3 \mathrm{H}), 2.06-2.02(\mathrm{~m}, 1 \mathrm{H})$, $1.96-1.88(\mathrm{~m}, 1 \mathrm{H}), 1.86-1.80(\mathrm{~m}, 1 \mathrm{H}), 1.70-1.50(\mathrm{~m}, 7 \mathrm{H}), 1.48-1.40(\mathrm{~m}, 5 \mathrm{H})$, $1.32-1.24(\mathrm{~m}, 6 \mathrm{H}), 1.23-1.18(\mathrm{~m}, 10 \mathrm{H}), 1.15(\mathrm{~s}, 3 \mathrm{H}), 1.10-1.00(\mathrm{~m}, 6 \mathrm{H})$ and $0.96-0.88(\mathrm{~m}, 3 \mathrm{H})$; HRMS (ESI) $\mathrm{m} / \mathrm{z}$ calculated for $\mathrm{C}_{51} \mathrm{H}_{84} \mathrm{ClN}_{4} \mathrm{O}_{15}\left(\mathrm{M}+\mathrm{H}^{+}\right)$ 1027.5622 , found 1027.5605

\section{$4^{\prime \prime}$-O-(((2,4-dichlorobenzamido)butyl)carbamoyl $)$ \\ AZM-11,12-carbonate (6e)}

White solid, yield $84.3 \%$, m.p. $165-168{ }^{\circ} \mathrm{C}$, TLC $\mathrm{R}_{\mathrm{f}}=0.34$ (methanol/dichlormethane, 1:10); IR (KBr): 3384, 3066, 2971, 2933, 2855, 1811, 1722, 1650, $1617,1590,1528,1452,1383,1314,1237,1167,1123,1105,1084,1045$ and $1015 \mathrm{~cm}^{-1} ;{ }^{1} \mathrm{H}$ NMR $\left(600 \mathrm{MHz}, \mathrm{CDCl}_{3}\right.$, $\delta$ p.p.m. $) 7.74(\mathrm{~d}, 1 \mathrm{H}, J=7.8 \mathrm{~Hz}), 7.56$ $(\mathrm{d}, 1 \mathrm{H}, J=7.8 \mathrm{~Hz}), 7.51(\mathrm{~d}, 1 \mathrm{H}, J=7.8 \mathrm{~Hz}), 5.02(\mathrm{~d}, 1 \mathrm{H}, J=4.8 \mathrm{~Hz}), 4.87$ (dd, $1 \mathrm{H}, J=9.0 \mathrm{~Hz}, J=6.0 \mathrm{~Hz}), 4.59(\mathrm{~d}, 1 \mathrm{H}, J=7.2 \mathrm{~Hz}), 4.53(\mathrm{~d}, 1 \mathrm{H}, J=9.6 \mathrm{~Hz})$, 4.44-4.36 (m, $2 \mathrm{H}), 3.80-3.72(\mathrm{~m}, 1 \mathrm{H}), 3.62-3.56(\mathrm{~m}, 1 \mathrm{H}), 3.56-3.40(\mathrm{~m}, 4 \mathrm{H})$, $3.30-3.20(\mathrm{~m}, 5 \mathrm{H}), 2.90-2.70(\mathrm{~m}, 9 \mathrm{H}), 2.48-2.42(\mathrm{~m}, 1 \mathrm{H}), 2.38-2.30(\mathrm{~m}, 1 \mathrm{H})$, 2.28-2.24 (m, 1H), $2.21(\mathrm{~s}, 3 \mathrm{H}), 2.06-2.02(\mathrm{~m}, 1 \mathrm{H}), 1.96-1.88(\mathrm{~m}, 1 \mathrm{H}), 1.86-$ $1.80(\mathrm{~m}, 1 \mathrm{H}), 1.70-1.50(\mathrm{~m}, 7 \mathrm{H}), 1.48-1.40(\mathrm{~m}, 5 \mathrm{H}), 1.32-1.24(\mathrm{~m}, 6 \mathrm{H})$, $1.23-1.18(\mathrm{~m}, 10 \mathrm{H}), 1.08-1.04(\mathrm{~m}, 3 \mathrm{H}), 1.02-0.96(\mathrm{~m}, 3 \mathrm{H})$ and $0.96-0.88$ $(\mathrm{m}, 6 \mathrm{H})$; HRMS (ESI) $\mathrm{m} / \mathrm{z}$ calculated for $\mathrm{C}_{51} \mathrm{H}_{83} \mathrm{Cl}_{2} \mathrm{~N}_{4} \mathrm{O}_{15}\left(\mathrm{M}+\mathrm{H}^{+}\right)$ 1061.5232, found 1061.5208.

\section{$4^{\prime \prime}-O-(($ 4-nitrobenzamido)butyl)carbamoyl $)$}

\section{AZM-11,12-carbonate (6f)}

White solid, yield $79.6 \%$, m.p. $125-128^{\circ} \mathrm{C}$, TLC $\mathrm{R}_{\mathrm{f}}=0.29$ (methanol/dichlormethane, 1:10); IR (KBr): 3396, 3067, 2973, 2934, 2873, 2675, 2623, 2605, 2497, $1811,1723,1656,1601,1526,1457,1383,1348,1299,1278,1237,1168,1123$, $1108,1075,1044$ and $1014 \mathrm{~cm}^{-1}$; ${ }^{1} \mathrm{H}$ NMR $\left(600 \mathrm{MHz}, \mathrm{CDCl}_{3}, \delta\right.$ p.p.m.) $8.23(\mathrm{~d}$, $2 \mathrm{H}, J=7.8 \mathrm{~Hz}), 8.10(\mathrm{~d}, 2 \mathrm{H}, J=9.6 \mathrm{~Hz}), 5.02(\mathrm{~d}, 1 \mathrm{H}, J=3.0 \mathrm{~Hz}), 4.90-4.84(\mathrm{~m}$, $1 \mathrm{H}), 4.56-4.48(\mathrm{~d}, 1 \mathrm{H}), 4.41(\mathrm{~s}, 1 \mathrm{H}), 4.30-4.16(\mathrm{~m}, 2 \mathrm{H}), 3.84-3.72(\mathrm{~m}, 1 \mathrm{H})$, 
3.62-3.36 (m, 3H), 3.36-3.20 (s, 5H), 3.14-3.06 (m, 2H), 2.90-2.70 (m, 9H), 2.50-2.30 (m, 2H), 2.26-2.16 (s, 4H), 2.06-2.02 (m, 1H), 1.96-1.88 (m, $1 \mathrm{H}$, $8-\mathrm{CH}), 1.86-1.80(\mathrm{~m}, 1 \mathrm{H}), 1.70-1.50(\mathrm{~m}, 7 \mathrm{H}), 1.48-1.36(\mathrm{~m}, 5 \mathrm{H}), 1.32-1.24$ $(\mathrm{m}, 6 \mathrm{H}), 1.24-1.12(\mathrm{~m}, 10 \mathrm{H}), 1.12-1.04(\mathrm{~m}, 3 \mathrm{H})$ and $1.00-1.02(\mathrm{~m}, 9 \mathrm{H})$; HRMS (ESI) $\mathrm{m} / \mathrm{z}$ calculated for $\mathrm{C}_{51} \mathrm{H}_{84} \mathrm{~N}_{5} \mathrm{O}_{17}\left(\mathrm{M}+\mathrm{H}^{+}\right)$1038.5862, found 1038.5835 .

\section{$4^{\prime \prime}$-O-(((3,5-dinitrobenzamido)butyl)carbamoyl)AZM-11,12- carbonate $(6 \mathrm{~g})$}

Slightly yellow solid, yield $83.5 \%, \mathrm{mp} 128-130^{\circ} \mathrm{C}$, TLC $\mathrm{R}_{\mathrm{f}}=0.28$ (methanol/ dichlormethane, 1:10); IR (KBr): 3423, 3105, 2972, 2936, 2878, 1812, 1726, $1670,1629,1543,1457,1382,1344,1301,1277,1237,1167,1110,1074,1045$ and $1015 \mathrm{~cm}^{-1}$; ${ }^{1} \mathrm{H}$ NMR $\left(600 \mathrm{MHz}, \mathrm{CDCl}_{3}, \delta\right.$ p.p.m.) 9.24-9.18 (m, $\left.2 \mathrm{H}\right)$, 9.18-9.12 (m, $1 \mathrm{H}), 5.09(\mathrm{~d}, 1 \mathrm{H}, J=4.8 \mathrm{~Hz}), 4.89(\mathrm{dd}, 1 \mathrm{H}, J=9.6 \mathrm{~Hz}, J=6.6 \mathrm{~Hz})$, $4.63(\mathrm{~d}, 1 \mathrm{H}, J=9.6 \mathrm{~Hz}), 4.46-4.30(\mathrm{~m}, 3 \mathrm{H}), 3.70-3.54(\mathrm{~m}, 4 \mathrm{H}), 3.38-3.22$ (m, 7H), 2.92-2.82 (m, 2H), 2.78-2.68 (m, $1 \mathrm{H}), 2.50-2.34(\mathrm{~m}, 8 \mathrm{H}), 2.20$ $(\mathrm{s}, 4 \mathrm{H}), 2.08-1.50(\mathrm{~m}, 10 \mathrm{H}), 1.48-1.38(\mathrm{~m}, 5 \mathrm{H}), 1.32-1.24(\mathrm{~m}, 6 \mathrm{H}), 1.24-1.14$ $(\mathrm{m}, 10 \mathrm{H}), 1.12-1.02(\mathrm{~m}, 6 \mathrm{H})$ and $0.96-0.88(\mathrm{~m}, 6 \mathrm{H})$; HRMS (ESI) $\mathrm{m} / \mathrm{z}$ calculated for $\mathrm{C}_{51} \mathrm{H}_{83} \mathrm{~N}_{6} \mathrm{O}_{19}\left(\mathrm{M}+\mathrm{H}^{+}\right)$1083.5713, found 1083.5691 (Supplementary Information).

\section{ACKNOWLEDGEMENTS}

This research was financially supported by National Natural Science Foundation of China (20872081 and 21072114), Major R\&D Program of New DrugsNational S\&T Key Special Subject of China (2009ZX09103-115), Natural Science Foundation of Shandong (ZR2010HM092) and the Project-sponsored by SRF for ROCS, SEM.
1 Chu, D. T., Plattner, J. J. \& Katz, L. New directions in antibacterial research. J. Med. Chem. 39, 3853-3874 (1996).

2 Morimoto, S., Takahashi, Y., Watanabe, Y. \& Omura, S. Chemical modification of erythromycins. I. Synthesis and antibacterial activity of 6-0-methylerythromycins A. J. Antibiot. 37, 187-189 (1984).

3 Djokic, S., Kobrehel, G. \& Lazarevski, G. Erythromycin series. XII. Antibacterial in vitro evaluation of 10-dihydro-10-deoxo-11-azaerythromycin A: synthesis and structureactivity relationship of its acyl derivatives. J. Antibiot. 40, 1006-1015 (1987).

4 File, T. M. Telithromycin new product overview. J. Allergy Clin. Immunol. 115, S1-S13 (2005).

5 Denis, A. et al. Synthesis and antibacterial activity of HMR 3647 a new ketolide highly potent against erythromycin-resistant and susceptible pathogens. Bioorg.Med. Chem. Lett. 9, 3075-3080 (1999).

6 Bryskier, A. Novelties in the field of anti-infectives in 1997. Clin. Infect. Dis. 27, 865-883 (1998).

7 Champney, W. S. \& Tober, C. L. Preferential inhibition of protein synthesis by ketolide antibiotics in Haemophilus influenzae cells. Curr. Microbiol. 46, 103-108 (2003).

8 Henninger, T. C. Recent progress in the field of macrolide antibiotics. Expert Opin. Ther. Pat. 13, 787-805 (2003)

9 Wu, Y. J. \& Su, W. G. Recent developments on ketolides and macrolides. Curr. Med. Chem. 8, 1727-1758 (2001).

10 Fernandes, P. B., Baker, W.R., Freiberg, L. A., Hardy, D.J. \& McDonald, E. J. New macrolides active against Streptococcus pyogenes with inducible or constitutive type of macrolide-lincosamide-streptogramin B resistance. Antimicrob. Agents Chemother. 33, 78-81 (1989).

11 Takashima, H. Structural consideration of macrolide antibiotics in relation to the ribosomal interaction and drug design. Curr. Top. Med. Chem. 3, 991-999 (2003).

$12 \mathrm{Ma}, \mathrm{S} ., \mathrm{Ma}, \mathrm{R}$. , Liu, Z., Ma, C. \& Shen, X. Synthesis and antibacterial activity of novel 15-membered macrolide derivatives: 4"-carbamate, 11,12-cyclic carbonate-4"-carbamate and 11,4"-di-O-arylcarbamoyl analogs of azithromycin. Eur. J. Med. Chem. 44, 4010-4020 (2009).

$13 \mathrm{Ma}, \mathrm{C}$. et al. Synthesis and antibacterial activity of novel 11,12-cyclic carbonate azithromycin 4"-O-carbamate derivatives. J Antibiot. 63, 3-8 (2010).

14 Schlünzen, F. et al. Structural basis for the antibiotic activity of ketolides and azalides. Structure. 11, 329-338 (2003).

Supplementary Information accompanies the paper on The Journal of Antibiotics website (http://www.nature.com/ja) 


\section{RETRACTION}

\section{Novel azithromycin derivatives with the $\mathrm{C}-4^{\prime \prime}$ bisamide side chains: synthesis and biological evaluation against gram-positive bacteria}

Wenping Cui, Lihong An, Chenchen Ma, Siti Ma, Chao Cong, Xin Li and Shutao Ma

Journal of Antibiotics advance online publication, 16 May 2012; doi:10.1038/ja.2012.35

Retraction to: The Journal of Antibiotics advance online publication,

15 February 2012; doi:10.1038/ja.2012.3

The corresponding author has indicated to the journal that this paper should be retracted as it is a duplicate publication. The author apologizes to the journal and its readers for any inconvenience caused. 